\title{
THE PURSUIT OF DECOLONISING AND TRANSFORMING CURRICULUM IN HIGHER EDUCATION
}

\author{
M. W. Lumadi \\ Department of Curriculum and Instructional Studies \\ University of South Africa \\ Pretoria, South Africa \\ e-mail: Lumadmw@unisa.ac.za / https://orcid.org/0000-0003-0121-7386
}

Decolonising higher education is an incredibly intricate and lengthy process. It should not be perceived as a prescribed blueprint but an arduous and contested process of unlearning and unpacking centuries of colonial ideas and infrastructures. Therefore, it cannot be expected that universities will find instant results. Instead, they should take giant steps towards unboxing the messy and perturbing effect of colonisation on their practices (Le Grange 2016).

The decolonisation of higher education should be viewed as a process of defying and dismantling the colonial systems that swayed education in the past and that are still perpetuated today. Colonial practices were established during times when nations-maintained supremacy over dependent territories. Moreover, decolonisation may also involve deliberating on the effect of colonisation on higher education and liberating curricula and the wider university culture from selective narratives. The foundational intent of decolonisation is to equip students with "diverse academic learning environments, curricula and approaches to research within which Indigenous cultures, histories, and knowledge are embedded" (Waghid and Hibbert 2018).

In response to colonial iconography, such as the Cecil Rhodes statue, and the marginalisation of Black, Asian and minority ethnic (BAME) students and staff, students at the University of Oxford called for the decolonisation of higher education. Students argued that the experiences and identities of BAME individuals were historically and systematically excluded from the institution. The Rhodes Must Fall campaigners claimed that, by having such a "Eurocentric curriculum", the institution "frames the West as sole producers of universal knowledge" (Oelofsen 2015; Abdi 2012).

In other words, there should be "proportional representation, advocating primarily for increased numbers of Indigenous, racialized, and low-income students and faculty, and the supplementation of existing curricula with non-Western perspectives." A decolonised 
curriculum should address the following key questions: Who is teaching? Who is being taught? What is the learning content? How is it being taught?

This means that the culture and the curricula of higher education institutions must meet the needs and interests of all students and staff, not just a selection. Universities should also review their curricula to ensure they are not dominated by a specific voice from the West. Many students felt that they were not represented by the curriculum because of this, and could not connect, or felt their voices were immaterial as a result. One of the ultimate aims of higher education is to provide all students with knowledge that will propel them towards further achievements in the future. If this knowledge is centred upon a specific experience, this not only presents a misleading image of history but also has the potential to be incredibly discouraging for minority students (Joseph 2009).

Given the central role of universities in social reproduction and the creation and legitimation of knowledge, decolonisation and its place in higher education serves as a subject of significant interest in both social movements and scholarly critique across the globe. The decolonisation of higher education is ultimately about creating a more welcoming and conducive environment for all staff and students. It is about building "a racism-free, inclusive environment that embraces the many diverse cultures present in the broader university community" (Mahabeer 2018).

More recent interpretations of decolonisation look at the lingering effects of colonial rule that are still present today, such as the use of English as the dominant language of instruction in higher education and the fact that many seminal texts are drawn from the West. Universities have a crucial role to play in this regard. It is the very vision and mission of universities to create intellectual discomfort and to stand for freedom of thought, thereby training citizens of the 21 st century who have the ability to address global challenges (Mbembe 2016; Wa Thiong'o 1998).

While the vision and mission of universities is strong, universities themselves need to be reimagined to become in tune with today's context. People are more connected than ever as a global community (Waghid 2014; López-Gopar 2016). Climate change, political and social polarisation, inequality - these are complex global challenges that demand a broad range of strategies and perspectives. Yet, many universities' convoluted curricula still have their roots in the late 18th and early 19th centuries, when the world was a very different place. In the hardcore version of decolonisation, African knowledge must replace Western knowledge at the centre of the African curriculum. 


\section{REFERENCES}

Abdi, A. A. 2012. Decolonising philosophies of education. Rotterdam: Sense Publishers.

Joseph, T. R. 2009. Decolonising the curriculum; transforming the university: A discourse perspective. London: Sage.

Le Grange, L. 2016. "Decolonising the university curriculum." South African Journal of Higher Education 30(2): 1-12.

López-Gopar, M. 2016. Decolonizing primary English language teaching. Bristol: New York Press.

Mahabeer, P. 2018. "Curriculum decision-makers on decolonising the teacher education curriculum." South African Journal of Education 38(4): 39-50.

Mbembe, A. J. 2016. "Decolonising the university: New directions." Arts and Humanities in Higher Education 15(1): 15-29.

Oelofsen, R. 2015. "Decolonisation of the African mind and intellectual landscape." Promina 16(2): 130-146.

Waghid, Z. 2014. "Education for social justice through sustainable development, economic development and equity." South African Journal of Higher Education 28(4): 1448-1463.

Waghid, Z. and L. Hibbert. 2018. "Decolonising preservice teachers' colonialist thoughts in higher education through defamiliarisation as a pedagogy." Educational Research for Social Change 7(1): 60-77.

Wa Thiong’o, N. 1998. “Decolonising the mind.” Diogenes 46(4): 101-104. 